\title{
Scleredema adultorum of Buschke in a child confirmed by special stains
}

\author{
Abhineetha Hosthota', Renu Kothottil', Seema Hegde Subraya² \\ ${ }^{1}$ Department of Dermatology, The Oxford Medical College, Hospital \& Research Center, Yadavanahalli, Bangalore, India, \\ ${ }^{2}$ Department of Pathology, The Oxford Medical College, Hospital \& Research Center, Yadavanahalli, Bangalore, India
}

Corresponding author: Dr. Abhineetha Hosthota, E-mail: abhineethahosthota@yahoo.com

Sir,

Scleredema adultorum of Buschke is an uncommon condition with unknown pathophysiologic characteristics. It is a misnomer as the condition can occur in childhood.Sudden onset after infection, insidious onset with paraproteinemias and those preceded by diabetes are the three types of scleredema [1].

Scleredema is characterized by diffuse shiny, symmetrical, non pitting and woody induration of skin. It usually begins on back, sides of neck and spreads to face, shoulders, arms, thorax and becomes generalized. The hands, feet and genetalia are usually spared [2]. There is no sharp demarcation between normal and abnormal skin. Wrinkling occurs when the skin is compressed between the thumb and index finger, indicating that the epidermis is spared. Disease reaches its peak in 1-2 weeks, may continue to spread for 2-3 months in some instances. History of diverse infections, from a few days to 6 weeks prior to onset is observed in $65-90 \%$ of cases [3]. Common infections are influenza, tonsillins pharyngitis, measles, mumps, scarlet fever, impetigo or cellulitis, prior streptococcal infections [3]. We report a case of scleredema confirmed by special stains in a male child.

A 6 years old boy presented with diffuse hardening of the skin on face, neck and upper trunk of 1 month duration. It was followed by 10 days after the acute febrile illness. The genitals and legs remained uninvolved. Past and family history was insignificant. Examination revealed shiny, symmetrical woody induration of the skin with no sharp line of demarcation between involved and uninvolved areas. There was lack of expression on face however, the movements of chest and abdomen were not affected. There was no clinically detectable systemic abnormality.

Haematological and urine examination was normal. Erythrocyte sedimentation rate (ESR) was raised (35 mm/h), absolute eosinophil count (AEC): 540 cells/cumm. Anti Nuclear antibody (ANA), lupus erythematosus (LE) phenomenon and anti streptolysin $\mathrm{O}(\mathrm{ASO})$ titre were negative. Chest X-ray showed streaky interstial opacities.

Histopathological examination showed no epidermal changes. Increase in the thickness of reticular dermis with separated collagen fibres were observed (Figs. la and b). Von Geisson stain showed swollen collagen bundles (Fig. 2a). Alcian blue ( $\mathrm{pH} 2.5$ ) stain shows deposition of mucin on the surface of collagen fibres and in the interfibrillar spaces (Fig. 2b).

Various differential diagnosis like scleredema, scleromyxedema and scleroderma were considered in our case. Histopathology of scleredema, epidermis and appendages are unaffected (Fig. la). There is thickening of reticular dermis with increased collagen fibres extending upto subcutaneous tissue (Fig. 1b). Where as flattening of epidermis, atrophy of pilosebaceous unit with marked proliferation of fibroblasts and increased collagen seen in upper and mid dermis in scleromyxedema. On Von Geisson stain, scleredema shows swollen collagen fibres separated from one another (Fig. 2a). In scleromyxedema collagen fibres are arranged in worled pattern. On Alcian blue staining, mucin deposition is seen on the surface of

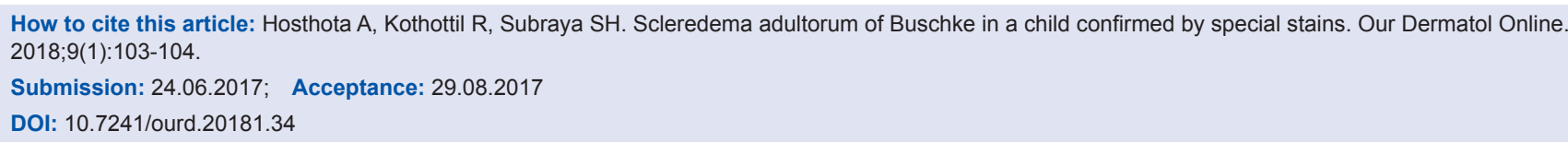




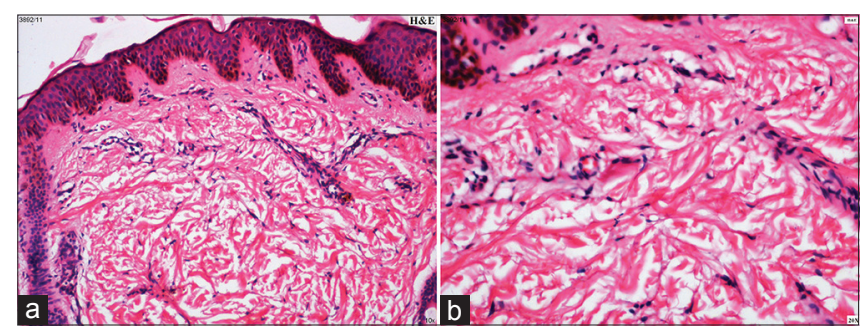

Figure 1: (a) Epidermis is normal with increased thickness of reticular dermis, (b) Increased collagen fibres in dermis.

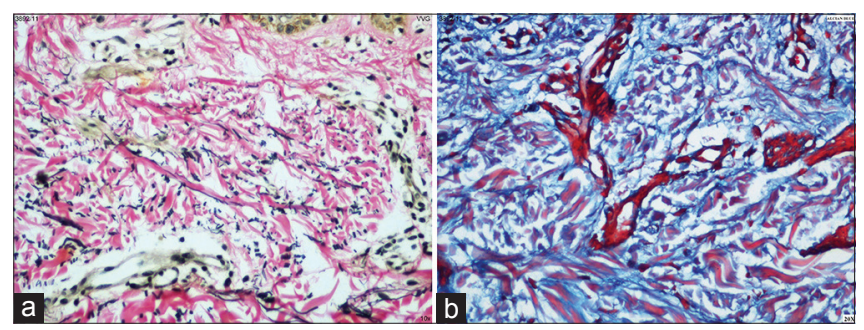

Figure 2: (a) Von Geisson stain: Swollen collagen fibres, (b) Alcian Blue: Mucin deposition in dermis.

collagen fibres in scleredema (Fig. 2b). However, in scleromyxedema deposits are seen in the upper and mid dermis [4].

In our case acute febrile illness could have triggered scleredema in a 6 years old boy. Scleredema is confirmed by clinical findings, histopathology and use of special stains for collagen and mucin.

Scleredema is a rare connective tissue disorder. It is characterized by the development of skin induration that resolves spontaneously [5]. It was originally described by Piffard in 1876. More common in children and females below the age of 20 years.

The pathogenesis of the condition is obscure, various causes have been proposed. These include immune sensitization phenomenon, hormonal stress reaction, lymphatic stasis, endocrine disturbance, enzyme dysfunction, dysautonomia [2]. Type I collagens and hyaluronate appear to be the major fibroblast products whose production is increased in scleraderma affected skin. The precise mechanisms for increased collagen and glycosaminoglycans production in sclerederma is uncommon [3].

Scleredema is a self limiting condition that resolves within 6 months to 2 years [3]. There is no effective treatment. Low dose oral steroids, intralesional corticosteroids, amoxicillin $750 \mathrm{mg}$ and clavulinic acid $75 \mathrm{mg}$ for 3 months with beneficial results [6]. Ciclosporin, electron beam therapy, PUVA using poralen cream, UVAl, extracorporel photopheresis and low dose methotrexate are more recent suggestions [7]. Since it is a self resolving condition, our patient was treated symptomatically and significant improvement is noted.

Histopathology and special stains are helpful for diagnosis of scleredema. This case is been reported because of the paucity of documented cases in Indian literature and establishes the significance of histopathology and special stains in the diagnosis of scleredema.

\section{REFERENCES}

1. Mittal RR, Gill SS, Arun S. Nodular amyloidosis associated with scleredema of Buschke. Ind J Dermatol Venereol Leprol. 1992;58:285-6.

2. Basavaraj KH, Prakash BG. Scleredema of Buschke. Ind J Dermatol. 1996;41:102-3.

3. Gupta V, Kumar M, Tripati AM. Ind J Dermatol Venereol Leprol. 1995; 61:185-6.

4. Cole HG, Winkelmann RK. Acid mucopolysaccharide staining in scleredema. J Cutan Pathol. 1990;17:211-3.

5. Singhal A, Ghandhi V, Bhattacharya SN. Scleredema adultorum of buschke associated with non-scarring alopecia of scalp. Ind J Dermatol Venereol Leprol. 1999;65:38-9.

6. Sayal SK, Sanghi S. Scleredema. Ind J Dermatol. 2003;48:184.

7. Anneli RB, Smith L, Zone JJ. Scleredema adultorum of buschke Treated With Radiation. Arch Dermatol. 2003;139:780-4.

Copyright by Abhineetha Hosthota, et al. This is an open-access article distributed under the terms of the Creative Commons Attribution License, which permits unrestricted use, distribution, and reproduction in any medium, provided the original author and source are credited.

Source of Support: Nil, Conflict of Interest: None declared. 